\title{
IMPLEMENTASI OBJEK JAMINAN KREDIT
}

\author{
Trisa Mardeta Putri, Paramita Prananingtyas, Anggita Doramia Lumbanraja \\ Program Studi Magister Kenotariatan \\ Fakultas Hukum, UniversitasDiponegoro \\ Email: trisamardeta26putri@gmail.com
}

\begin{abstract}
The position of the creditor as the holder of the Underwriting Right has the priority in paying off debts by the debtor. The collateral object for the land that is charged with the Underwriting Right has a certain period of time, but if the Building Use Rights object that is charged with the Underwriting Right is exhausted before the debt is paid, this will cause problems. This research study about how does the legal power of the Right to Use of Building End and what efforts do the creditors to defend their rights. The nature of the study is normative juridical. The author found that if the object of the Right to Use of Building has ended, the previous holder of the Right to Use of Building is not entitled to the collateral object, the Mortgage Certificate has an executorial nature that protects the debtor's right to auction the object. Efforts can be made to extend the term of the Mortgage Rights and sell / pawn the debtor's assets to pay off debts.
\end{abstract}

Keywords : creditor; mortgage objects.

\begin{abstract}
Abstrak
Kedudukan kreditor sebagai pemegang Hak Tanggungan mempunyai sifat yang diutamakan dalam pelunasan hutang oleh debitor. Objek jaminan atas tanah yang dibebankan dengan Hak Tanggungan memiliki jangka waktu tertentu, namun apabila objek Hak Guna Bangunan yang dibebankan Hak Tanggungan habis sebelum hutang dilunasi maka akan menimbulkan persoalan. Penelitian ini hendak mengkaji tentang bagaimana kekuatan hukum Hak Guna Bangunan yang berakhir dan apa upaya yang dilakukan kreditur untuk mempertahankan haknya. Sifat penelitian adalah yuridis normatif. Penulis menemukan apabila objek Hak Guna Bangunan telah berakhir maka pemegang Hak Guna Bangunan sebelumnya tidak berhak atas objek jaminan tersebut, sertifikat Hak Tanggungan mempunyai sifat eksekutorial yang melindungi hak debitur untuk melakukan pelelangan atas objek tersebut. Upaya yang dapat dilakukan memperpanjang jangka waktu dari Hak Tanggungan dan menjual/menggadaikan harta kekayaan debitor guna pelunasan hutang.
\end{abstract}

\section{Kata Kunci: kreditur; hak tanggungan}

\section{A. Pendahuluan}

Lembaga perbankan memiliki fungsi sebagai penghimpun dan penyalur dana masyarakat, yang salah satu implementasinya dimasyarakat merupakan memberikan kredit. Perkreditan mencakup aspek pembangunan seperti bidang perdagangan, perindustrian, perumahan, transportasi dan sebagainya dalam hal tersebut yang menjadi penunjang bagi pertumbuhan ekonomi negara. Sistem pengkreditan bertujuan melindungi masyarakat ekonomi lemah karena kesulitan menyediakan dana dalam mengembangkan dan memulai usaha. Sistem pengkreditan 
sebagai solusi untuk masyarakat mendapatkan dana lebih cepat, sebagian masyarakat ekonomi lemah dapat memanfaatkan fasilitas ini guna mengembangkan usahanya (Mangunkusumo, 1985).

Pada prinsipnya pencairan kredit oleh bank tidak slalu harus diikuti dengan adanya agunan, karena jaminan sudah dianggap ada dengan melihat peluang dan prosepek usaha yang cerah dari calon debitor. Penyaluran Kredit yang bersifat ekspansif tersebut di satu sisi sudah barang tentu sangat menguntungkan masyarakat karena akan dapat dengan mudah memperoleh dana (dalam bentuk kredit atau pinjaman bank) tanpa harus disertai syarat yang rumit dan merepotkan.

Bank sebagai lembaga yang menyalurkan dana ke masyarakat, salah satunya dalam bentuk pinjaman. Pinjaman yang diberikan seringkali menimbulkan kerugian pada bank. Faktor yang menyebabkan kerugian karena nasabah atau debitor tidak dapat mengembalikan sejumlah uang pinjaman dan sejumlah bunga hutang debitor. Suatu pinjaman bank secara ekspasif atau pemberian pinjaman tanpa agunan sering kali mengakibatkan kemacetan kredit, disebabkan bank tidak tepat dalam melakukan balancing of interest yakni memadukan antara orientasi keuntungan debitor untuk menjaring seluruh peluang bisnis, guna pengembalian dana - dana yang sudah disalurkan (Khoidin, 2017).

Hak Tanggungan merupakan hak atas tanah yang dibebani hak istimewa, memberikan kedudukan yang diutamakan bagi kreditur untuk mendapatkan pelunasan hutang. (Harsono, 1999). Bahwa dalam hal ini kreditur mempunyai hak atas tanah untuk menjual dan mengeksekusi, objek jaminan yang diberikan debitur guna pelunasan hutang apabila debitur tidak dapat memenuhi prestasinya.

Hak jaminan bersifat hak kebendaan adalah memberikan langsung kekuasaan terhadap bendanya. Tujuan pemberian hak jaminan khusus yang bersifat dari kebendaan itu adalah untuk memberikan hak verhaal (hak meminta pemenuhan piutang) kepada debitur manakala dia wanprestasi. Pemenuhan diambil dari hasil penjualan benda -benda milik debitur. Ciri yang khas dari sifat kebendaan pada hak - hak jaminan adalah dapat dipertahankan dari siapapun dan senantiasa mengikuti bendanya (droit de suite, zaakgevolg). Artinya, hak jaminan yang bersifat kebendaan senantiasa mengikuti bendanya di tangan siapapun benda tersebut berada (Sumardi, 1985). 
Hak jaminan bersifat perorangan menimbulkan hubungan langsung antara perorangan yang satu terhadap yang lain. Jaminan yang bersifat perorangan memberikan hak verhaal kepada kreditur terhadap perorangan lain selaku penjamin (penanggung) manakala debitur tidak dapat memenuhi prestasinya. Pihak penjamin dapat terlebih dahulu meminta agar kreditur mengajukan tuntutan terhadap harta kekayaan debitur (Khoidin, 2017).

Hak Guna Bangunan memiliki batas waktu 25 tahun, dalam jangka waktu tersebut hak guna bangunan dapat dipergunakan dengan cara dikelola maupun dijaminkan. Hak guna bangunan yang dijaminkan pada saat itu masih memiliki rentang waktu sebelum habis masa keberlakuannya, sehingga bank menerima objek hak guna bangunan tersebut sebagai jaminan, namun ternyata masa berlaku dari hak guna bangunan tersebut habis sebelum utang atas jaminan hak guna bangunan sebagai objek hak tanggungan yang dibebankan kepada debitur dilunasi. Sehingga hal ini menimbulkan permasalahan terhadap kekuatan hukum dari jaminan hak guna bangunansebagai objek hak tanggungan.

Teori-teori yang digunakan dalam penulisan ini adalah Teori Perjanjain, Teori Perjanjian merupakan perjanjian jaminan bersifat accessoir (tambahan) yaitu senantiasa merupakan perjanjian yang dikaitkan dengan perjanjian pokok. Perjanjian dalam proses pengkreditan mempunyai dua jenis perjanjian yaitu perjanjian pokok dan perjanjian tambahan. Perjanjian pokok ialah perjanjian yang mengikatkan antara kreditor dan debitor, berkaitan dengan hutang yang akan dipinjam. Perjanjian tambahan merupakan perjanjian pelengkap berisi tentang agunan/ jaminan yang diberikan debitor sebagai bentuk kesanggupan debitor untuk melunasi hutangnya, adapun bentuk jaminan yang seringkali diterima oleh bank seperti Hak Tanggungan, Jaminan fidusia dan sebagainya. Perjanjian penjaminan secara tersendiri merupakan tambahan yang dikaitkan dengan perjanjian pokok tersebut (Sofwan, 2007).

Ketentuan umum mengenai persetujuan diatur didalam Bab II sedangkan ketentuan khusus diatur didalam Bab V s/d XVIII ditambah Bab VII A. Ketentuan - ketentuan umum mengenai terjadinya dan hapusnya perikatan seperti yang terdapat dalam Bab I dan Bab IV pun bertalian dengan perikatan yang terjadi karena persetujuan.(Setiawan, 1986) Menurut ketentuan Pasal 1313 KUHPerdata menyatakan bahwa "Suatu perjajian adalah suatu perbuatan dengan mana satu orang atau lebih mengikatkan dirinya terhadap satu oranglain atau lebih "(KITAB UNDANG - UNDANG HUKUM PERDATA, 2013). 
Teori Eksekusi adalah ketentuan mengenai eksekusi lahir dari suatu janji (beding) yang diberikan oleh pemberi hak jaminan kepada penerima hak, yaitu janji untuk menjual benda jaminan atas kekuasaan sendiri (beding van eigenmachtige verkoop). Dalam gadai, hak untuk menjual atas kekuasaan sendiri diberikan oleh Undang - Undang Pasal 1155 KUHPerdata yang berbunyi

"Seorang kawan waris yang telah memindatangankan seluruhnya atau sebagian apa yang tlah di bagikan kepadanya, tidaklah dapat meminta pembatalan pemisahan harta peninggalan atas alasan telah terjadi paksaan atau, penipuan jika pemindahtanganan itu dilakukan sesudah terhentinya paksaan atau sesudah diketahuinya penipuan tersebut" (Muljadi, 2006).

Hipotik dan Hak Tanggungan harus diperjanjikan oleh debitur dengan kreditur. Pemberi dan penerima Hak Tanggungan tingkat pertama dapat memperjanjikan hak untuk menjual obyek Hak Tanggungan atas kekuasaan sendiri jika debitur wansprestasi. Janji tersebut, terutama dalam hipotik, pada awalnya diatur dalam Pasal 1178 ayat (2) Kitab Undang-Undang Hukum Perdata, Agar janji untuk menjual atas kekuasaan sendiri yang tercantum dalam akta pemberian hak tanggungan yang dibuat debitur dan kreditur mempunyai kekuatan mengikat, maka harus didaftarkan.

Berkenaan dengan hak - hak kreditur tersebut diatas, bagaiaman untuk jaminan - jaminan yang memiliki jangka waktu terbatas. Jaminan yang memiliki jangka waktu terbatas salah satunya adalah Hak Tangguangan. Adapun contoh kasus, jaminan seorang debitur kepada bank berupa tanah bersetifikat Hak Guna Bangunan pada waktu terjadinya kesepakatan/penandatangan perjanjian kredit, masa berlaku dari jaminan hak atas tanah masih berlaku, seiring perjalanan waktu pengkreditan, bank tidak menyadari bahwa jangka waktu dari jaminan debitur tersebut berakhir sedangkan jatuh tempo waktu pelunasan hutang debitur masih lama. Jaminan hak guna bangunan yang sudah berakhir maka akan dikembalikan penguasaanya ke negara, kreditur yang memegang jaminan tersebut tidak memiliki kewenangan atas bangunan itu. Kreditur masih memiliki haknya atas pelunasaan hutang oleh debitur karna dasar perjanjian pokok utang piutang tidak hapus meskipun berakhirnya perjanjian tambahan.

Berdasarkan dari jurnal penelitian penulis lain, memiliki perbedaan dalam pembahasan dan rumusan masalah yang terdapat dalam jurnal ini, salah satu contohnya adalah jurnal penelitian yang berjudul "perlindungan hukum pemegang hak tanggungan yang obyeknya dikuasai pihak ketiga berdasarkan perjanjian sewa menyewa" menjelaskan bahwa perlindungan 
hukum terhadap pemegang objek Hak Tanggungan yang sudah dialihkan melalui jual beli atau jaminan hutang kepada kreditor, tidak membatalkan perjanjian sewa menyewa tersebut antara debitor (sebagai pemegang hak tanggungan sebelumnya) dan pihak ketiga (penyewa). Berdasarkan Pasal 1576 BW. Berbunyi sebagai berikut:

"Pelaksanaan dijualnya barang yang disewa, suatu persewaan yang dibuat sebelumnya, tidaklah diputuskan kecuali apabila ini telah diperjanjikan pada waktu menyewakan barang. Jika ada suatu perjanjian yang demikian, si penyewa tidak berhak menutut suatu ganti rugi apabila tidak ada suatu janji yang tegas, tetapi jika ada suatu janji seperti tersebut belakangan ini, ia tidak diwajibkan mengosongkan barang yang disewa, selama ganti rugi yang terutang belum dilunasi."

Tanggung jawab kreditor sebagai pemegang Hak Tanggungan yang baru ialah mengausai dan mengeksekusi dari objek tersebut. Kreditor tidak memiliki Tanggung jawab apapun kepada penyewa untuk memberikan ganti rugi, namun perjanjian sewa menyewa sebelumnya tidak dapat dibatalkan. Penyewa harus merelakan objek Hak Tanggungan yang dikuasainya apabila kreditor meneksekusi objek tersebut, persoalan ganti kerugian bisa dimintakan kepada debitor. Sedangkan dalam jurnal ini penulis membahas tentang eksekusi objek hak tanggungan yang sudah habis masa keberlakuannya sebelum utang dari debitur terselesaikan. Penulis memfokuskan upaya yang harus dilakukan oleh kreditur untuk tetap mempertahankan haknya mendapatkan pelunasan hutang. Kedudukan kreditur yang awalnya sebagai preferen/diistimewakan berubah menjadi kreditur kongkuren, tentunya hak istimewa mendapatkan pelunasan hutangpun berakhir.

Jurnal dari penelitian lain yang berjudul "pembebanan hak tanggungan terhadap objek tanah yang belum terdaftar bersamaan permohonan pendaftaran tanah pertama kali” membahas tentang proses pembebanan objek Hak Tanggungan yang belum terdaftar di Kantor Pertanahan. Bahwa secara yuridis hal ini diizinkan menurut Pasal 10 ayat (3) Undang-undang Hak Tanggungan Nomor 4 Tahun 1996. Pelaksanaan proses pembebanan hak tanggungan dan perdaftaran tanah pertama kali terhadap objek tanah memiliki resiko tertentu. Hal ini berkaitan dengan informasi data objek tanah yang belum ada sebelumnya sehingga pembebanan hak tanggungan tersebut dikhawatirkan penilaiannya berakibat kerugian bagi pihak ketiga (Bank). Bank menerapkan prisip kehati-hatian dalam memberikan kredit kepada debitor. Kegiatan pendaftaran objek tanah pertamakali kadangkala ditemukan sengketa sehingga apabila hak tanggungan tersebut berjalan beriringan, dikhawatirkan perncairan kreditpun akan bermasalah karena Bank tidak memiliki jaminan bahwa objek Hak Tanggungan tersebut dinyatakan bersih 
bebas sengketa (Imron, A, 2014). Sedangkan pembahasan jurnal ini, mengkaji tentang kekuatan hak guna bangunan yang sudah habis masa berlakunya, namun masih sebagai objek hak tanggungan atas utang debitur yang belum dilunasi. Bahwa sebelumnya kreditur yang berkedudukan sebagai kreditur preferen berubah menjadi kreditur kongkuren, karna objek dari jaminan hak tanggungan tersebut menjadi hapus.

Eksistensi Hak Tanggungan Sebagai Lembaga Jaminan Hak Atas Tanah (Tinjauan Filosofis) membahas tentang Lembaga Jaminan (Hak Tanggungan) menjadi solusi bagi para pengusaha yang akan merintis karir maupun yang akan mengembangkan usahanya. Perkembangan ekonomi yang begitu pesat menjadikan persaingan usaha semakin ketat. Pelaku usaha harus memiliki langkah untuk tetap mempertahankan usahanya dengan melakukan kredit di bank. Pengkreditan menunjang untuk pelaku usaha bergerak cepat menyediakn modal agar dapat menggerakan roda ekonominya. Kemunculan hak tanggungan sebagai lembaga jaminan hak sangat mendukung, sekaligus dengan masuknya investor asing ke Indonesia serta terbukanya kemungkinan bagi WNA/badan hukum asing untuk mendapat hak pakai atas tanah Negara dan menjadikannya sebagai jaminan untuk memperoleh modal/kredit di Indonesia guna menunjang kegiatan perekonomian di Indonesia. (Nurjannah, 2018) sedangkan dalam jurnal ini membahas tentang objek hak tanggung sebagai jaminan atas utang, yang habis masa keberlakuannya sebelum utang atas jaminan tersebut dilunasi oleh debitur, yang mana mengakibatkan perubahan kedudukan dari pihak kreditur sebagai kreditur preferen menjadi kreditur kongkuren.

\section{B. Metode Penelitian}

Pendekatan yang digunakan dalam penelitian ini adalah normatif. Penelitian ini berupa penelitian perpusatakaan atau studi dokumen, yang mengumpulkan peraturan-peraturan yang tertulis atau bahan - bahan hukum yang lain yang menunjang penelitian ini.

\section{Hasil Dan Pembahasan}

1. Kekuatan hukum dari hak guna bangunan sebagai objek hak tanggungan yang dalam masa jaminannya sudah habis masa berlakunya 
Perjanjian (Verbintenis) merupakan hubungan antara dua orang atau lebih untuk melaksanakan sebuah prestasi dan memperoleh prestasi, berkaitan dengan harta kekayaan, sekaligus membuat peraturannya sendiri dan harus disepakati oleh para pihak, berlaku seperti undang - undang bagi para pihak yang membuatnya (Harahap, 1982). Perjanjian adalah suatu peristiwa dimana seseorang berjanji kepada orang lain atau dimana dua orang atau lebih itu saling menentukan kehendaknya untuk melaksanakan sesuatu. Suatu hal tersebut, dibuat bentuknya sebagai perjanjian dapat diaplikasikan sebagai rangkaian perkataan yang mengandung janji-janji tentang kesanggupan terhadap prestasi yang diucapkan melaui lisan atau tertulis dan pemenuhan kehendak yang diinginkan para pihak (Subekti, 1987).

Berdasarkan pendapat Wirjono Prodjodikoro, menyatakan perjanjian adalah suatu hubungan hukum berhubungan dengan harta benda kekayaan antara dua pihak atau lebih, Adapun kedudukan salah satu pihak berjanji untuk melakukan sesuatu keinginan sedangkan disisilain untuk tidak melakukan sesuatu hal, sedangkan pihak lain menuntut pelaksanaan janji itu (Prodjodikoro, 1981). Para ahli lain mengatakan salahsatunya, menurut R.Setiawan, perjanjian merupakan suatu rangkaian perbuatan hukum yang harus ditaati oleh para pihak yang bersepakat uutuk mengikatkan dirinya atau saling menentukan kehendak dirinya terhadap satu orang atau lebih (Setiawan, 1987). Sri Soedewi Masjchoen Sofwan, berpendapat bahwa perjanjian merupakan perbuatan hukum dimana seseorang atau lebih mengikatkan dirinya terhadap seorang lain atau lebih (Masjchoen,S, 2003).

Peristiwa hukum dengan pemenuhan prestasi salah satunya ialah perjanjian utang piutang uang berhubungan erat bersama harta kekayaan termasuk ke jenis perjanjian pinjam-meminjam. Hal ini berdasarkan peraturan bab ketiga belas buku ketiga KUHPerdata Pasal 1754 kuh perdata menyebutkan, bahwa pinjam - meminjam merupakan perjanjian dengan mana salah satu pihak memberikan kepada pihak lain, suatu jumlah tertentu berbentuk benda atau barang dapat habis karena pemakaian, sedangkan dilain sisi pihak yang menerima tersebut harus memenuhi syarat akan mengembalikan sejumlah dengan jenis dan kondisi semula (Supramono, 2013).

Konsep dan filosofi hak jaminan atas tanah dalam hukum Adat berbeda dengan hukum Barat.Dalam Hukum Adat menggunakan tanah sebagi jaminan hutang merupakan perbuatan persiapan. Artinya pada saat peminjam menerima pinjaman, maka seketika itu sudah 
ditetapkan tanah pertanian yang akan dipakai sebagai benda jaminan pelunas hutang (delgingsoverenkomst). Dengan demikian maka perjanjian uang itu diganti dengan perjanjian tanah (Syamsul, 2001). Gadai Tanah dalam hukum adat merupakan salah satu bentuk trandaksi jual tanah.Oleh karna itu tanah yang digadaikan dikuasai dan diambil manfaatnya oleh pemberi pinjaman. Tidak hanya itu pemberi pinjaman (yang menurut konsep hukum barat disebut kreditur) dapat memiliki tanah untuk selamanya jika dijual kepadanya atau jika peminjam tidak dapat melunasi hutangnya. Ciri-ciri ini tidak terdapat dan bahkan dilarang dalam hak jaminan menurut Hukum Barat.

Penggunaan istiah "Tanggungan" juga sulit dicari padangannya dalam bahasa inggris. Berbeda dengan kata hipotik atau mortgage yang sudah mendunia dan dikenal banyak negara baik yang menganut sistem hukum Anglosaxon (mortagage) maupun sistem hukum Romawi (hipotik).(Undang - undang Nomor 5 tahun 1960 tentang Peraturan dasar pokok agraria, 1960) Iming Tesalonika mencoba menterjemahkan kata "Tanggungan" dengan "Encumbrance", sehingga istilah hak tanggungan diterjemahkan menjadi Encumbrance Right.

Hak Guna Bangunan mempunyai sifat kepemilikan horizontal. Bahwa pemilik bangunan diatas sebuah tanah seringkali bukan orang yang sama dengan pemilik tanah. Pemilik hak guna bangunan yang berdiri diatas tanah berstatus hak milik, mempunyai jangka waktu paling lama tigapuluh tahun, namun dapat melakukan perpanjangan melalui negosiasi kepada pemilik tanah menurut (Peraturan pemerintah Nomor 40 tahun 1996 tentang Hak guna usaha, hak guna bangunan dan hak pakai atas tanah, 1996). Proses yang harus dilakukan pertama, datang ke Badan Pertanahan Nasional untuk melakukan pemberitahuan bahwa hak atas tanah tersebut dilakukan perpanjangan penguasannya kepada pemegang Hak Guna Bangunan sebelumnya. Apabila hak atas tanah yang berubah atau turun status haknya maka segala pembebanan hak diatas tanah tersebut menjadi hapus dengan kata lain akan ada perjanjian baru antara pemegang Hak Guna Bangunan dengan Pemilik Hak atas tanah.

Pertimbangan kreditor melakukan penilaian secara seksama dijamin oleh undangundang sebagaimana ditentukan dalam Pasal 8 UU Perbankan (Undang - undang Nomor 10 Tahun1998 Tentang Perbankan, 1998). Bahwa dalam kegiatan menyalurkan kredit, bank harus mempunyai keyakinan berdasarkan analisis yang benar atas latar belakang debitior 
dan itikad baik bertujuan untuk bertanggung jawab dengan perjanjian kredit, diiringi dengan kejujuran memberikan segala bentuk informasi yang dibutuhkan bank. Hal ini berkaitan dengan kemampuan dan kesanggupan debitor secara harta kekayaan dimilikinya, untuk melunasi utang atau mengembalikan pembiayaan dimaksud sesuai dengan yang diperjanjikan. Keyakinan yang dimaksud sebelum memberikan kredit, akan muncul apabila bank melakukan penilaian secara seksama terhadap watak, kemampuan, modal, agunan, dana prospek usaha dari debitor (Ngadenan, 2010).

Ketentuan yang ditetapkan oleh pihak Bank merupakan bentuk dari antisipasi bank untuk menghindari persoalan kredit macet atau kredit yang terhambat pelunasannya oleh debitur.Kriteria sedemikian tersebut mengingat tujuan dari kreditor meminta jaminan tersebut apabila debitur cidera janji atau tidak dapat melunasi dari kredit yang dibebankan. Kreditor menginkan dari jaminan debitur karna apabila harus dilaksanakannya eksekusi letak dari jaminan yang strategis dapat mrenjamin "harga yang tinggi" untuk dibawak ke pelelangan selain itu peminat dari peserta lelang pada benda jaminan akan lebih banyak karna dianggap menguntungkan. Namun pada pratiknya apabila debitur sudah mulai tersendat untuk melunasi kredit, maka biasanya pihak bank akan menawarkan kepada debitur untuk menjual benda jaminan tersebut kepada pihak lain terkait hal ini pihak lain tersebut (pembeli) akan dibantu untuk dicarikan oleh pihak bank, yang gunannya agar pihak lain tersebut dapat melanjutkan dari kredit yang belum selesai oleh debitur sebelumnnya.

Hak Guna Bangunan sudah habis sedangkan kredit dari debitor belum selesai maka dengan secara langsung agunan yang meletak pada Hak Bangunan tersebut hapus atau Hak Tanggungan dari kredit tersebut hilang.Sedangkan hapusnya Hak Tanggungan tidak lagi sebagai jaminan secara khusus berdasarkan kedudukan istimewa kreditor, melainkan hanya sebagai jaminan umum berdasarkan pasal 1131 KUHPerdata.Dengan demikian dapat merugikan kreditor karna kehilangan dari haknya atas jaminan benda yang menjadi Hak Tanggungan sebelumnya. Namun kreditor dapat mempertahankan dari haknya untuk tetap mendapatkan pelunasan hutang, karna segala barang milik debitur yang bergerak serta, yang akan ada, menjadi jaminan atas hutang - hutang yang dimiliki debitur.

Berdasarkan ketentuan Pasal diatas maka terhadap objek jaminan berupa Hak Guna Bangunan yang masa jaminannya telah habis masa berlakunya kembali kepada ketentuan tersebut diatas. Setelah terjadinya objek jaminan berupa Hak Guna Bangunan yang masa 
jaminannya sudah habis maka kedudukan istimewa yang sebelumnya dimiliki kreditur ikut hapus seiring dengan habisnya masa jaminan Hak Guna Bangunan yang dibebankan dengan Hak Tanggungan tersebut habis, hal ini berdasarkan ketentuan Pasal 18 UUHT tentang hapusnya Hak Tanggungan karena hapusnya hak atas tanah yang dibebankan dengan Hak Tanggungan. Setelah kedudukan kreditur berubah yang sebelumnya kreditur preferen menjadi kreditur konkuren maka pembagian atas pelunasan utang tersebut berdasarkan ketentuan Pasal 1132 UUHT yang menerangkan barang-barang milik debitur menjadi jaminan bersama bagi kreditur lainnya kecuali ada hal-hal tertentu untuk didahulukan.

\section{Upaya Hukum Pihak Kreditur Hak Tanggungan Dengan Objek Hak Guna Bangunan}

\section{Yang Masa Jaminannya Sudah Habis Masa Berlakunya}

Wanprestasi senantiasa diawali dengan hubungan kontraktual (characteristics of default is always preceded by a contarctual relationship). Kontrak merupakan bentuk instrument yang secara khusus mengatur hubungan hukum antara dua orang atau lebih menurut kepentingan yang bersifat privat/perdata. Hal ini berkaitan tentang kehendak dari para pihak untuk menentukan presetasi sehingga akan melahirkan peraturan yang harus dipatuhi keduanya. Kepentingan masyarakat individu dalam kontrak sangat diutamakan namun selain dari pada itu harus mempetimbangkan kepentingan masyarakat umum. Kepentingan masyarakat umum meliputi peraturan yang hidup dan berkembang dimasyarakat menjadi sebuah hal yang tidak dapat dikesampingkan untuk pertimbangan dalam pembuatan kontrak seperti norma kesusilaan, ketertiban umum, agama dan sebagainya. (Varia, 2008)

Konsep prestasi merupakan domain dalam hukum perdata. Berdasarkan pasal 1234 KUHPerdata menyatakan tujuan dari perikatan yaitu untuk memberikan sesuatu, berbuat sesuatu atau tidak berbuat sesuatu. Penjelasan maksud dari memberikan sesuatu ialah tindakan dari salah satu pihak untuk memenuhi kewajiban memberikan prestasi baik dalam bentuk benda atau perbuatan apapun yang sudah disepakati, disisilain ada pihak yang mempunyai hak untuk menerima atas pemenuhan prestasi tersebut. Dimaksud dengan berbuat sesuatu adalah menyerahkan hak milik atau memberikan kenikmatan atas sesuatu benda. Tidak berbuat sesuatu adalah perbuatan tidak melakukan apapun demi kepentingan prestasi tersebut. Apabila ketentuan tersebut tidak dijalankan sesuai dengan peraturan yang disepakati maka akan menimbulkan wanprestasi berakibat merugikan salah satu pihak dan memberikan keuntungan bagi pihak lain. (Yahman, 2014) 
Berdasarkan dari uraian diatas yang mana membahas tentang prestasi menurut ketentuan Pasal 1234 KUHPerdata. Bahwasanya wanprestasi merupakan suatu perbuatan yang diawali dengan perjanjian, perbuatan yang dimaksud dapat berupa berbuat sesuatu, tidak berbuat sesuatu, memberikan sesuatu. Dikaitkan dengan persoalan diatas yang Hak Guna Bangunan sudah habis masa berlakunya termasuk dalam perbuatan wanprestasi. Mengapa demikian karna izin Hak Guna Bangunan yang sudah habis berlakunya, sedangkan jangka waktu dari perjanjian kredit belum jatuh tempo, maka apabila izin Hak Guna Bangunan tersebut sudah habis sebelum diperpanjangnya mengakibatkan Hak Guna Bangunan yang dibebankan dengan Hak Tanggungan tersebut ikut hapus. Jadi atas perjanjian kredit tersebut dengan jaminan objek Hak Guna Bangunan menjadi hapus.

Perpanjangan hak adalah proses pengajuan/permohonan guna penambahan jangka waktu izin menguasai/mengelola hak atas tanah berstatus Hak Guna Bangunan yang sebentar lagi akan habis masa keberlakuannya, pejabat yang berwenang memberikan izin perpanjangan jangka waktu ialah Badan Pertanahan Nasional, kepada pemegang hak atas tanah tersebut. Pengertian pembaruhan hak adalah Proses pendaftaran/permohonan guna pembaruhan/pemulihan atas status hak atas tanah yang tidak berlaku lagi dikarenakan telah berakhir masa keberlakuannya sehingga pemegang hak atas tanah tersebut diharuskan untuk melakukan pendaftaran baru kepada pejabat yang berwenang untuk dapat mepergunakan hak atas tanah itu. (Retno, 2008)

Sertifikat hak tanggungan merupakan alat pembuktian yang kuat bagi adanya hak (kewenangan) bertindak bagi kreditur untuk melindungi kepentingannya. Kekuatan dari pembubuhan kata-kata DEMI KEADILAN YANG BERDASARKAN KETUHANAN YANG MAHA ESA, dalam sertifikat itu. Ditafsirkan sebagai alat pembuktian sempurna untuk melaksanakan eksekusi tanpa harus adanya putusan pengadilan dan melindungi kepentingan kreditur. Pada suatu keadaan debitor berada dalam kondisi wanprestasi (cidera janji) maka kreditor mempunyai hak untuk dapat mengeksekusi secara langsung barangbarang milik debitur yang menjadi agunan melalui proses penyitaan dan penjualan lelang. Bahwa kreditor pemegang jaminan hak tanggungan merupakan kreditur kongkuren artinya kreditur tersebut memiliki hak prioritas untuk mendapatkan pembayaran secara lebih awal. (Pertiwi, 2013)

Pada praktiknya bank mengindari jalan terakhir untuk menyita barang dari debitur. Bank lebih berusaha untuk mempertahankan kredit dari debitur untuk dibayar secara berkala sesuai perjanjian. Pelaksanaan dilapangan yang sering dilakukan bank untuk membantu 
debiturnya adalah menjadwalkan kembali kredit bersangkutan. Apabila upaya pencegahan oleh bank untuk menghindari kredit macet gagal dan debitur masih tidak dapat membayar hutangnya maka pihak bank akan melelang jaminan milik debitur sebagai pemenuhan hutangnya.

Bank sebagai lembaga penyedia kredit harus berhati - hati dalam memberikan penilaian terhadap calon debitur dan objek jaminan yang akan dijaminkan. Hal ini berkaitan dengan jangka waktu dan kemampuan dari debitur untuk melunasi hutangnya sebelum jatuh tempo kredit berakhir. Jaminan hak guna bangunan memiliki jangka waktu tertentu sehingga bank seharusnya menyesuaikan antara masa pembenanan hak guna bangunan sebagai objek hak tanggungan dan jangka waktu pelunasan kredit debitur. Apabila masa dari hak guna bangunan akan berakhir, sedangkan objek tersebut masih dalam jaminan hak tanggungan maka pemegang hak atas tanah (HGB-nya) segera melakukan perpanjangan agar sertifikat HGB masih tetap berlaku.

Jangka waktu hak guna bangunan yang sudah berakhir namun masih dibebankan dengan hak tanggungan, artinya kekuataan atas tanah tersebut tidak ada lagi yang berwenang pada objek hak atas tanah (HBG) habis masa keberlakuannya, kembali ke negara, jadi kekuatan dari objek tersebut sebagai Hak tanggungan juga ikut hapus. Akibat atas berakhirnyanya jangka waktu benda yang dijaminkan sekaligus menghapus pembebanan objek tersebut dari jaminan hutang debitur.

Berdasarkan ketentuan Pasal 18 Ayat (1) UUHT huruf d bahwa sebab-sebab hapus Hak Tanggung diantaranya, hapusnya hak atas tanah yang dibebani Hak Tanggungan, dengan demikian apabila masa waktu dari izin Hak Guna Bangunan yang di bebani Hak Tanggungan sudah habis, sebelum jatuh tempo dari masa utang piutang debitur, maka akibatnya Hak Tanggungan yang membebani dari objek Hak Guna Bangunan tersebut ikut hapus seiring berakhinya Hak Guna Bangunannya.

Berdasarkan ketentuan Pasal 18 Ayat (4) UUHT menerangkan hapusnya Hak Tanggungan karena hapusnya hak atas tanah yang dibebani Hak Tanggungan tidak menyebabkan hapusnya hutang yang dijamin. Dengan demikian utang yang dimiliki debitur tidak semerta- merta hapus atau berakhir, kreditur masih mempunyai hak untuk mendapatkan pelunasan hutang terkait dengan ini ada ketentuan yang mengaturnya yaitu Pasal 1131 KUHPerdata bahwa segala harta benda milik debitur baik yang bergerak maupun tidak bergerak, yang ada maupun yang akan datang menjadi jaminan atas piutang atau perikatan yang dimilikinya.Meskipun apabila dikembalikan pada Pasal 1 UUHT yang mengatakan 
bahwa Pemberi Hak Tanggungan memiliki kedudukan yang diutamakan dari kreditur kreditur lainnya namun hal ini dianggap berakhir bagi kreditur dikarenakan sudah berakhirnya masa dari pembebanan Hak Tanggungan tersebut.

Demikian dapat dikatakan bahwa kedudukan dari kreditur preferen sudah berakhir seiring dengan berakhirnya atau hapusnya dari pembebanan Hak Tanggungan atas Hak Guna Bangunan yang sudah berakhir jangka waktunya. Maka kedudukan dari kreditur berubah menjadi kreditur kongkuren yang mana diatur dalam ketentuan 1131 KUHPerdata yang dimaksud diatas serta berdasarkan ketentuan Pasal 1132 KUHPerdata barang - barang yang menjadi jaminan bersama, terhadap hasil penjulan tersebut diberikan sesuai dengan besaran utang oleh debitur.

\section{Simpulan}

Bahwa berakhirnya jangka waktu dari hak atas tanah (HGB) sebagai objek hak tanggungan, sekaligus menghapus pembebanan sebagai benda jaminan hutang pada objek itu. Kreditur preferen berubah menjadi kreditur kongkuren karena tidak ada lagi jaminan objek hak atas tanah dari debitur. Kedudukan kreditur kongkuren berdasarkan pasal 1131 KUHPerdata segala kebendaan milik debitur, baik yang bergerak atau tidak bergerak, baik yang sudah ada maupun belum ada, sekaligus benda yang akan ada dikemudian hari menjadi jamianan atas segala hutangnya.

Bahwa upaya yang dapat dilakukan kreditur untuk mempertahankan haknya dengan mempertimbangkan kondisi dari objek jaminan tersebut, apabila jangka waktu dari hak guna bangunannya akan berakhir maka langkah yang dapat dilakukan mengajukan perpanjangan objek jaminan yang dibebankan hak tanggungan tersebut. Berakhirnya jangka waktu hak guna bangunan sedangkan hutang dari debitur belum dilunasi maka tidak menghapus perjanjian hutang piutang antara kreditur dan debitur. Perubahan kedudukan kreditur preferen sebagai pemegang objek jaminan berubah menjadi kreditur kongkuren yang memiliki hak yang sama dengan kreditur lain untuk mendapatkan peluasan hutang dari seluruh harta kekayaan debitur miliki.

\section{DAFTAR PUSTAKA}

\section{Buku}

Harahap, M. (1982). Segi segi hukum perjanjian. Bandung: Alumni.

Harsono, B. (1999). Hukum Agraria Indonesia ( Sejarah Pembentukan Undang-undang Pokok Agraria, Isi dan Pelaksanaannya). Jakarta: Djembatan. 
Imron,A, K. (2014). Pembebanan hak tanggungan terhadap objek tanah yang belum terdaftar bersamaan permohonan pendaftaran tanah pertama kali. Repertorium, IV(Desember), 13.

Khoidin, M. (2017a). Hukum Jaminan. Surabaya: laksbang yustitia.

Khoidin, M. (2017b). Hukum Jaminan. Surabaya: Lasbang yustitia.

Mangunkusumo, S. (1985). Aspek - aspek Hukum Perkreditan Golongan Ekonomi Lemah. Jakarta: BPHN Departement Kehakiman.

Masjchoen,S, S. (2003). Hukum jaminan di Indonesia. Yogyakarta: Liberty Offset.

Muljadi, K. (2006). Perikatan Yang Lahir Dari Perjanjian. Jakarta: PT. Raja Grafindo.

Peraturan pemerintah Nomor 40 tahun 1996 tentang Hak guna usaha, hak guna bangunan dan hak pakai atas tanah. , (1996).

Prodjodikoro, W. (1981). Hukum perdata tentang persetujuan - persetujuan tertentu. Bandung: Sumur Bandung.

Retno, E. W. (2008). Pemberian kredit dengan jaminan Hak tanggungan yang objek tanah statusnya Hak Guna Bangunan di PT. BRI cab. Tegal. Universita Diponegoro.

Setiawan, R. (1986). Pokok- pokok Hukum Perikatan. Bandung: Bina Cipta.

Setiawan, R. (1987). Perikatan - perikatan pada umumnya. Bandung: Bina Cipta.

Sofwan, S. M. (2007). Hukum Jaminan di Indonesia Pokok - Pokok Hukum Jaminan dan Jaminan Perorangan. Yogyakarta: Liberty Offset.

Subekti, R. (1987). Hukum Perjanjian (Cet. 12). Jakarta: PT. Intermasa.

sumardi, mangunkusumo. (1985). Aspek - aspek Hukum Perkreditan Golongan Ekonomi Lemah, kertas kerja dalam Simposium Aspek - aspek Hukum Masalah Perkreditan. Jakarta: BPHN Departement Kehakiman.

Supramono, G. (2013). Perjanjian Utang Piutang. Jakarta: Kencana.

Syamsul, B. (2001). Eksisteni, Fungsi dan Ralita serta Masa Depan Hak Gadai Tanah Pertanian Setelah Berlakunya Undang - Undang Pokok Agraria. Disertasi Program Pascasarjana Unair.

Varia. (2008). Yurispudensi Mahkamah Agung RI. Jakarta.

Yahman. (2014). Karakteristik Wanprestasi dan Tindak Pidana Penipuan. Jakarta: Kencana.

\section{Jurnal}

Ngadenan. (2010). Eksekusi hak tanggungan sebagai konsekuensi jaminan kredit untuk perlindungan hukum bagi kepentingan kreditur dimungkid. Law Reform, 5(April), 77.

Nurjannah, S. (2018). Eksistensi hak tanggungan sebagai lembaga jaminan hak atas tanah (Tinjauan Filosofis). Jurisprudentie, 5(juni), 204.

Pertiwi, D. (2013). Perlindungan hukum pemegang hak tanggungan yang obyeknya dikuasai pihak ketiga berdasarkan perjanjian sewa menyewa. Jurnal Ilmiah Mahasiswa Universitas 
Surabaya, 2(nomor 2), 80 .

\section{Undang - undang dan Peraturan}

Kitab Undang - Undang Hukum Perdata.

Undang - undang Nomor 4 Tahun 1996 tentang Hak Tanggungan.

Undang - undang Nomor 5 Tahun 1960 tentang Peraturan Dasar Pokok Agraria.

Undang - undang Nomor 10 Tahun1998 Tentang Perbankan.

Peraturan Pemerintah Nomor 40 Tahun 1996 tentang Hak Guna Usaha, Hak Guna Bangunan Dan Hak Pakai Atas Tanah. 